\title{
Actors, Conflict, and Comeptition in Iraq's Disputed Territories After the Islamic State: The Cases of Northren Diyala and Eastern Salahaddin
}

\author{
Dr. Zmkan Ali Saleem*
}

\author{
Dr. Mac J. Skelton**
}

Keywords: Conflict, Islamic State, Iraq, Northren Diyala, Eastern Salahaddin.
\[ \underline{\text { https://doi.org/10.31271/jops. } 10030} \]

\begin{abstract}
This article examines the emerging security, political, and economic dynamics in Iraq's Internally Disputed Boundaries (DIBs) following the defeat of Islamic State (IS) and the withdrawal of the Kurdish security forces from those areas. The research focuses on two vital but unappreciated areas of the DIBs: Tuz Khurmatu and northern Diyala. As the vast majority of the media and policy attention is directed towards either Kirkuk, due to oil interests, or the Nineveh Plains, due to the presence of vulnerable ethnic minorities, the other centres of the DIBs receive insufficient consideration among scholars, policy makers and development practitioners. Some NGOs have gone so far as to make a policy of avoiding Tuz and northern Diyala altogether due to the difficulty of local conditions and the ever-present potential for violence. This is a grave error. The DIBs cannot be resolved without engaging these two regions, as they are strategically important for commercial and political reasons, and any final deal on the status of the DIBs between Baghdad and Erbil will have to include them.
\end{abstract}

\footnotetext{
* Lecturer at College of Political Sciences - University of Sulaimani: zmkan.saleem@univsul.edu.iq ** Researcher at American University of Iraq, Suleimani (AUIS): mac.skelton@auis.edu.krd
} 


\section{يوختهى تويَزَينهوه:

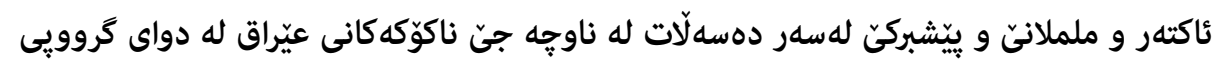

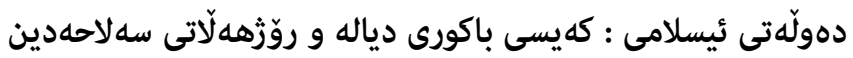

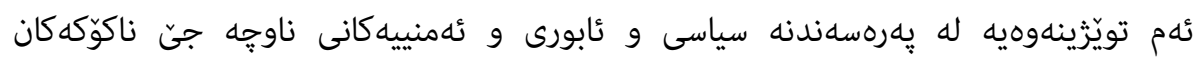

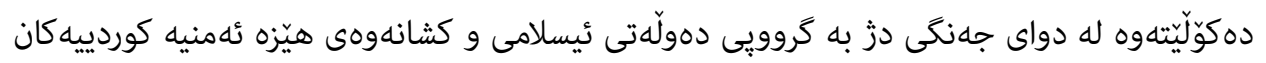

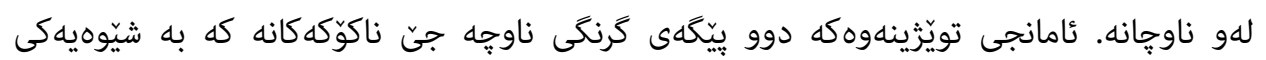

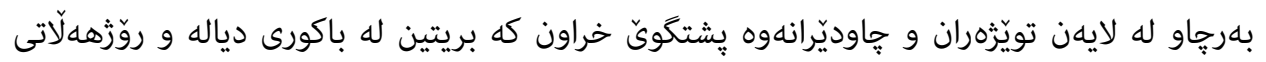

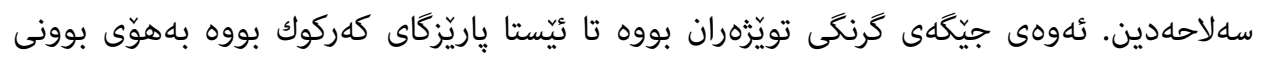

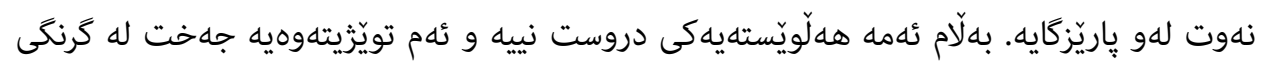

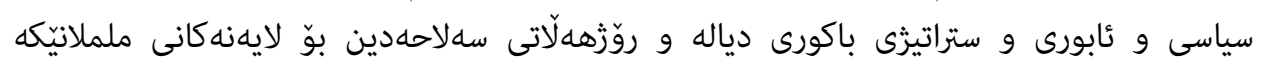

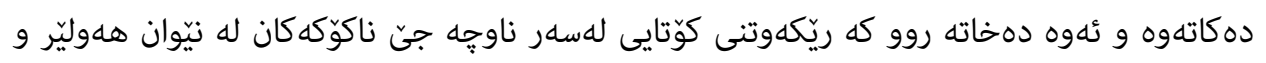

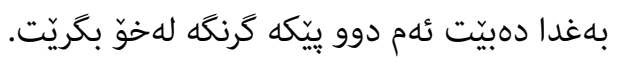

\section{ملخص البحث:}

الجهات الفاعلة والصراع و المنافسة في المناطق المتنازع عليها في العراق ما بعد الدولة الإسلامية:

حالتي شمال ديالى وشرق صلاح الدين

يتناول هذ البحث الديناميات الأمنية والسياسية والاقتصادية الناشئة في المناطق العراقية المتنازع

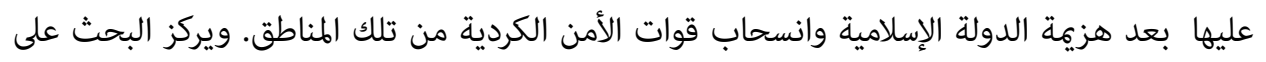

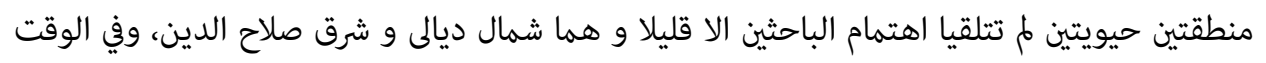

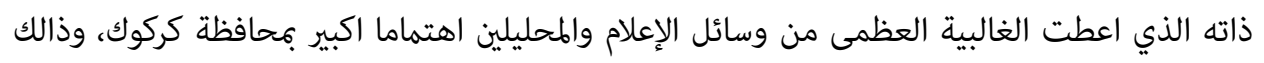

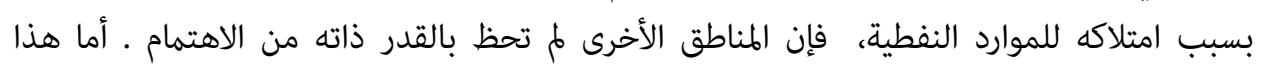

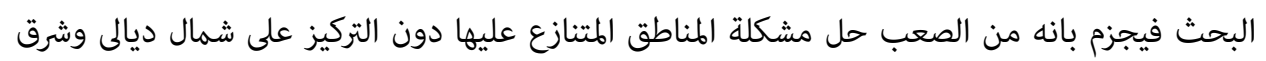

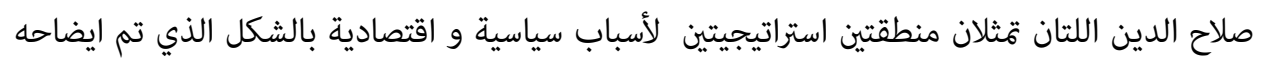

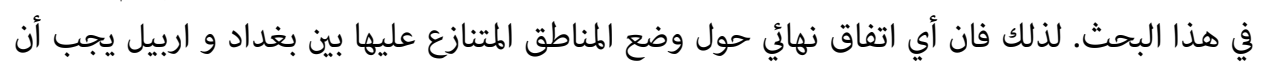
يشمل منطقتي شمال ديالى وشرق صلاح الدين. 


\section{Introduction}

The appointment of Adil Abdulmahdi as Iraq's Prime Minister after the general elections of May 2018 has ushered in a sense of optimism about the future of relations between the Iraqi federal governmmet in Baghdad and the Kurdistan Regional Governmnet (KRG) in Erbil. Since his arrival to power, Abdulmahdi, refered to by both observes and Iraqi politicians as "close to the Kurds", has allied with Kurdish concerns and avoided escalations with the KRG on the main outstanding issues between Baghdad and Erbil. In addition to financial issues (oil revenue sharing and oil investment) and military matters (the status of Kurdish Peshmerga Forces), conflict over Iraq's Internally Disputed Boundaries (DIBs) between Erbil and Baghdad has become a central destabilising feature of the post2003 era. Despite this, the Iraqi governmnet under Abdulmahdi has so far failed to propose a roadmap twards solving the status of DIBs between Erbil and Baghdad while the issue could resurface again at anytime with dire consequences for domestic security and stability of Iraq and the KRG. Therfeore, the issue of Iraq's DIBs deserve greater scholarly attention.

Two major events - the rise of the Islamic State (IS) in 2014 and the Kurdish independence referendum of 2017 -have generated a change in the nature of the conflict, transforming a two-sided dispute over sovereignty into a many-side struggle for localised control. The withdrawal of federal troops in the face of the IS assault created a security vacuum, a void that a number of armed groups, including the Peshmerga and various branches of the Popular Mobilization Forces (PMF) would quickly fill through liberation operations. In October 2017, shortly after the ill-fated Kurdish referendum of September 2017, the (KRG) political and military hold over large swaths of the disputed territories evaporated overnight. How have these key changes impacted upon the dynamics of conflict and competition in the Nortren Diyala and Eastren Salahaddin parts of the (DIBs)? Further, how do these changes complicate addressing the issue of (DIBs) in the future? The research stands to answer these questions by assessing and analysing the emerging actors in the two areas of (DIBs) in focus and the means through which these actors have attempted to achieve their goals. 


\section{Scope and Objectives}

The aim of this study is to understand the evolution of the DIBs conflict from a two-dimensional contest over sovereignty to a multi-sided competition between rival military and political groups. The research focuses on two vital but unappreciated areas of the DIBs: Tuz Khurmatu - and northern Diyala. As the vast majority of the media and policy attention is directed towards either Kirkuk, due to oil interests, or the Nineveh Plains, due to the presence of vulnerable ethnic minorities, ${ }^{(1)}$ the other centres of the DIBs receive insufficient consideration among scholars, policy makers and development practitioners. Some NGOs have gone so far as to make a policy of avoiding Tuz and northern Diyala altogether due to the difficulty of local conditions and the ever-present potential for violence. This is a grave error. The DIBs cannot be resolved without engaging these two regions, as they are strategically important for commercial and political reasons, and any final deal will have to include them.

\section{Method}

The research mainly relied on local fieldwork and interviews conducted by the authors, in each locality analysed. The targeted sample group has varied according to the context. The researchers used existing contacts to map out an initial list of key relevant officials and actors involved in security, administration and civil society, and then followed additional leads. A total of 4 interviews were conducted between 1 August and 1 December 2018. Interviewees included: governors of provinces; provincial council members; district and subdistrict council members; local commanders of Badr and AAH; members of the Iraqi Security Forces (ISF), Federal Police and Rapid Response Forces (RRF); heads of the political branches of Badr, AAH, Patriotic Union of Kurdistan (PUK) and the Kurdistan Democratic Party (KDP); local businesspeople; humanitarian and development workers; and smugglers and others involved in illicit trade.

The research also draws upon literature and desk study analysis, which sought to contextualise conflict in the DIBs within a broader historical and sociological

\footnotetext{
(1) See BBC News, 'Iraq takes disputed areas as Kurds 'withdraw to 2014 lines', BBC online, 2017. Available at https://www.bbc.com/news/world-middle-east-41663350; Stefan Wolff, 'Governing (in) Kirkuk: resolving the status of a disputed territory in post-American Iraq', International Affairs, 86.6 (2010): 1361-1379.
} 
context. Sources included federal and KRG records, data on incidents of violence and conflict, election results, data on displacement and news sources in Arabic, Kurdish and English. The literature review focused generally on the disputed territories and specifically on the three areas examined in this report.

\section{Conceptual Framework}

In the analysis of the cases, the research employs two key concepts. First, the political marketplace refers to 'transactional politics that facilitate the purchase of political loyalties in exchange for material reward', ${ }^{(2)}$ creating a dominance of patronage relations across the entire political hierarchy. ${ }^{(3)}$ The disputed territories of Iraq have become an intense battleground for competing entities to gain support through the extension of jobs, contracts and services to ethnically aligned and/or supportive constituents. Second, moral populism refers to the 'ability to both mobilise and divide populations by deploying exclusivist religious and ethnic rhetoric'. ${ }^{(4)}$ The various groups vying for influence in the DIBs have attempted to employ an ethnosectarian or nationalist rhetoric that mobilises local support, inflaming ethnosectarian affiliations and emphasising Kurdish-ness or Shi 'a-ness, respectively. While both moral populism and the political marketplace drive conflict in Tuz and northern Diyala, they are manifested to varying degrees. In northern Diyala, the key dynamic driving instability is the political marketplace, as different groups compete over a war economy that fuels patronage networks. In Tuz Khurmatu, moral populism has generated intense episodes of intercommunal violence.

\footnotetext{
(2) Toby Dodge et al., 'Iraq Synthesis Paper: Understanding the Drivers of Conflict in Iraq', LSE Middle East Centre-Conflict Research Programme, 2018. Available at: http://www.lse.ac.uk/international-development/Assets/Documents/ccs-research-unit/ConflictResearch-Programme/crp-synthesis-paper/Iraq-synthesis-paper-understanding-the-drivers2018.pdf.

(3) Alex de Waal, 'Introduction to the Political Marketplace for Policymakers', JSRP Policy Brief, March 2016.

(4) Toby Dodge et al., 'Iraq Synthesis Paper: Understanding the Drivers of Conflict in Iraq'
} 
2. Background on Iraq's Disputed Territories in the Light of Recent Changes

After the US-led invasion of Iraq in 2003, portions of Nineveh, Kirkuk, Salahaddin and Diyala were designated as 'disputed territories' or 'disputed internal boundaries' under Iraq's 2005 constitutional Article 140. (See map 1) The article held that local referenda were to occur in order for their final status could be determined. Such referenda never occurred, and instead a competition between the Kurdish Regional Government (KRG) and the Government of Iraq (GoI) became entrenched across the territories. ${ }^{(5)}$ The Kurds made the first series of moves, partly because they were emboldened by the disproportionate favour of US forces. Soon after the fall of the regime in 2003, the KRG expanded its influence across the disputed territories. In some areas of the DIBs, the Peshmerga, the KRG controlled forces, were granted control over ground security in coordination with the Coalition Forces. More importantly, the KRG's extensive payroll enabled the regional government to gain support through patronage politics. The GoI escalated its engagement with the DIBs in the 2008 to 2014 period, coinciding with the withdrawal of US troops in 2011. As part of the broader divide-and-rule sectarian politics espoused by Iraq's former Prime Minister Nouri al-Maliki (2006-2014), the Baghdad-based Shi a parties gained inroads into the DIBs by empowering co-religionists such as the Shi 'a Turkmen, whom they supported with access to salaries and services.

\footnotetext{
(5) Peter Bartu, 'Wrestling with the integrity of a nation: the disputed internal boundaries in Iraq', International Affairs. 1 Nov 2010; 86(6):1329-43.
} 
Map (1): Iraq's Internally Disputed Boundaries

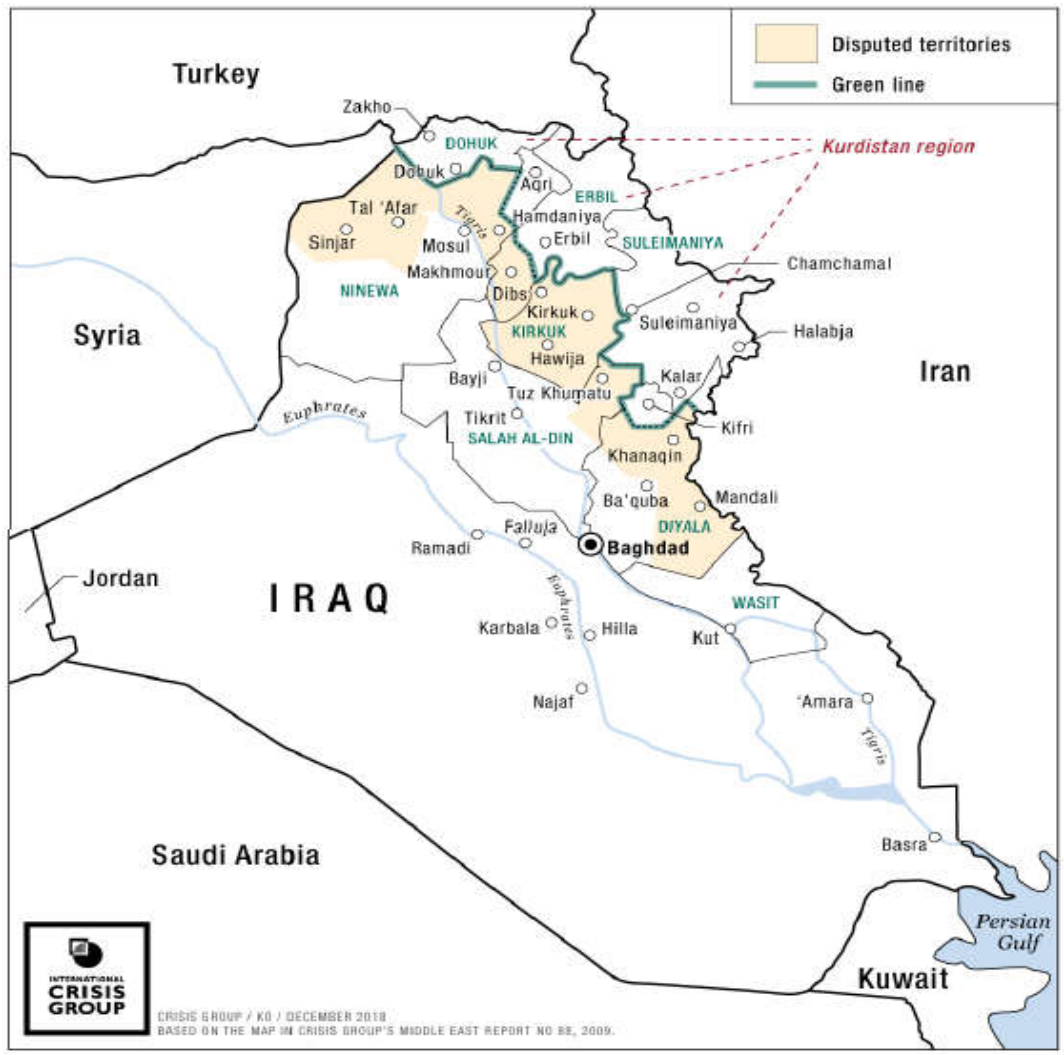

Source: International Crisis Group:

https://d2071andvip0wj.cloudfront.net/194-reviving-un-mediation-on-iraq-sdisputed-internal-boundaries.pdf

The state-funded PMF is by no means a monolith. It is a vast umbrella organisation over numerous armed groups with varying degrees of loyalty to the GoI, Iran and other group-specific interests. ${ }^{(6)}$ The Badr Organization, ${ }^{(7)}$ the largest

\footnotetext{
${ }^{(6)}$ Renad Mansour and Fālih 'Abd al-Jabbār, 'The Popular Mobilization Forces and Iraq's Future', Carnegie Endowment for International Peace, 2017. Available at: https://carnegiemec.org/2017/04/28/popular-mobilization-forces-and-iraq-s-future-pub-68810
} 
of the PMF, is simultaneously aligned with, and competing against, other factions, such as the pro-Iran Asa 'ib Ahl al-Haq (AAH), Kata' ib Hezbollah, and various PMF comprised of minority groups, such as the Assyrian Christian Nineveh Plain Protection Units and the Shabak Shi ${ }^{\text {a PMF }}{ }^{\left({ }^{8}\right)}$ As these disparate forces moved into the DIBs along with Kurdish and Iraqi armies in anti-ISIS military operations, the area became a site of multi-sided struggle for post-liberation control.

While the Kurds made serious gains during the 2014-17 period and enjoyed full control of the strategically important Kirkuk, the tables soon turned in favour of the PMF and GoI with the Kurdish referendum. In the ill-timed and controversial independence referendum of September 2017, Kurdish parties ensured that votes were cast across many areas of the DIBS, a strong provocation against GoI claims to sovereignty. The referendum created momentum in Baghdad for a full onslaught against Kurdish control over the DIBs. ${ }^{(9)}$ In October 2017, a mixture of the Iraqi Army and PMF moved northward and soon took control over the disputed areas of Kirkuk, Diyala, Saladin and Nineveh. The GoI-backed side regained total security control over the disputed territories and expelled both KRG security forces and much of the administrative personnel. Kurdish forces now stand at the 2003 borders, a development that represents a huge territorial loss.

\section{The Case Studies}

The GoI reassertion of power has not entailed an end to the struggle over control. Not only do the Kurdish political parties remain active in many areas of the

\footnotetext{
(7) Guido Steinberg, 'The Badr Organization: Iran's Most Important Instrument in Iraq', German Institute for International and Security Affairs, 2017. Available at: https://www.swp berlin.org/fileadmin/contents/products/comments/2017C26 sbg.pdf

${ }^{(8)}$ Erica Gaston and András Derzsi-Horváth, 'Iraq after ISIS: An Analysis of Local, Hybrid, and Sub-State Security Forces', GPPi, 27 December 2017. Available at: https://www.gppi.net/2017/12/27/iraq-after-ISIS-an-analysis-of-local-hybrid-and-sub-state-securityforces

(9) Loveday Morris, 'How the Kurdish independence referendum backfired spectacularly', The Washington Post, 20 October 2017. Available at: https://www.washingtonpost.com/world/how-thekurdish-independence-referendum-backfired-/2017/10/20/3010c820-b371-11e7-9b93-
} b97043e57a22_story.html?utm_term $=.728 \mathrm{~b} 97 \mathrm{fb} 523 \mathrm{~b}$ 
DIBs, but the GoI and state-backed PMF are fractured into numerous armed groups and political parties. The territories are now an arena for conflict between numerous entities, all of which use ethno-sectarian ideology, threats of violence, the political marketplace and the struggle to dominate institutions as a way to compete with others. At the same time, residents from all ethno-sectarian backgrounds point to the weakness of the government and express disinterest in the state. There is a general sense of confusion around who has the authority to make decisions and how services can be administered. In the next sections, the focus will be shifted to assessing and analysing the cases of Northren Diyala and Eastren Salahaddin.

\subsection{Northern Diyala: Competition over the Political Marketplace}

The northern Diyala district of Khanaqin is strategically important for commercial, security and political reasons. The region is inhabited by large Kurdish, Arab (Shi 'a and Sunni), and Turkmen populations perceived by Kurdish and Baghdad-based parties as significant voting blocs. The district centre is majority Kurd (85 percent), ${ }^{(10)}$ while large populations of both Kurds and Sunni Arabs reside in the subdistricts of Jalawla and Sadiyah. The district is rich in oil and produces major revenues via two border crossings with Iran, the Mounzariah and Paruezkhan crossings. Given the district's proximity to the Kurdistan Region of Iraq (KRI), the semi-autonomous Kurdish government sought to exert its influence by whatever means possible. Between 2003 and 2014, the KRG and particularly PUK succeeded in mobilising support within the district centre, where the Kurds of the large Fayli tribe tend to lean politically towards the Kurdish region. ${ }^{(11)}$ Extensive KRG payrolls cemented the support of local employees, including many non-Kurds. The KRG made payments of money and cars to Arab tribal leaders in Jalawla and Sadiyah in exchange for loyalty, ${ }^{(12)}$ and provided employment for Arabs and Turkmen in all three cities. This not only ensured Kurdish dominance but also garnered support

\footnotetext{
${ }^{(10)}$ Interview with Muhammed Mulla Hassan, Mayor of Khanaqin, September 2018.

(11) The Fayli Kurds are religiously Shi ' a but align politically along ethnic lines with their fellow Sunni Kurds in the KRG.

(12) Interview with member of the PUK branch in Khanaqin (Head of Election Division) in Khanaqin, October 2018.
} 
among non-Kurdish communities for the eventual annexation of Khanaqin into the KRI.

Map (2) Iraq’s Diyala Governorate

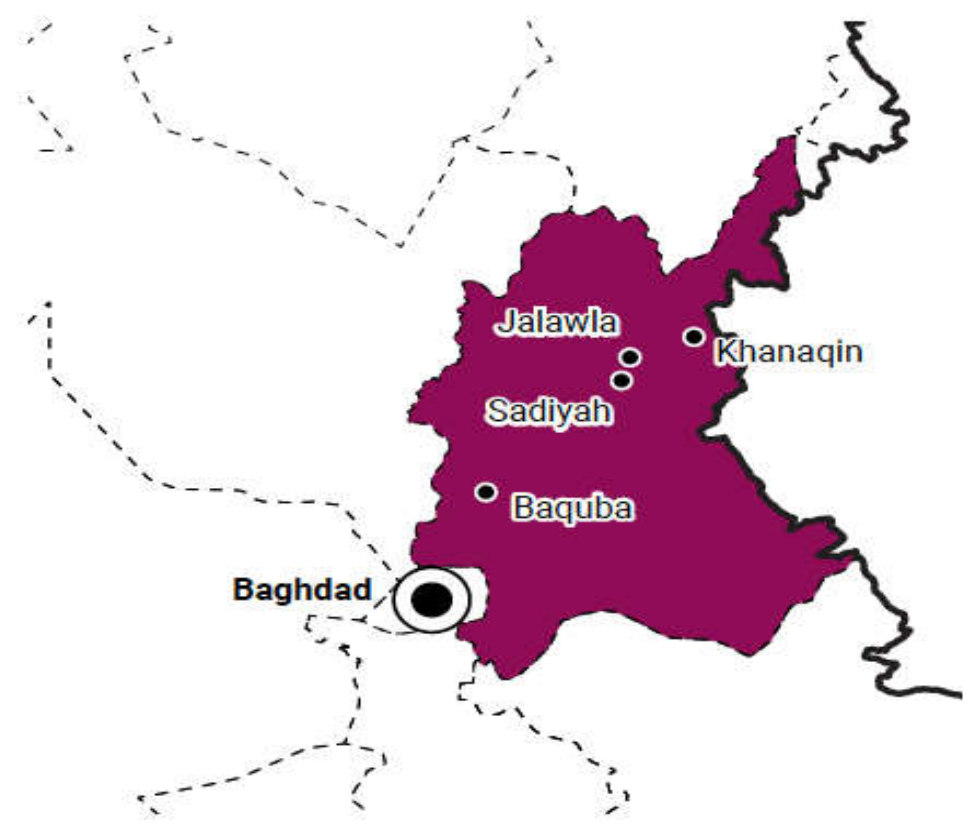

\section{Source:}

https://reliefweb.int/sites/reliefweb.int/files/resources/reach_irq_map_iraq_dyala_refe rence_18jul2016.pdf

This high-stakes political marketplace would soon have to contend with the entrance of new and powerful actors. Beginning in 2008, Nouri al-Maliki set his sights on Khanaqin and pledged to assert GoI control, largely in response to protests from his political base over perceived Kurdish expansionism across the disputed territories. The former Prime Minister provoked a major political crisis when he sent Iraqi troops to Khanaqin, demanding that all 4,000 Peshmerga fighters retreat from the city. While KRG President Masoud Barzani and Maliki ultimately agreed on a compromise that placed the Peshmerga to the north and ISF to the south of the 
city, ${ }^{(13)}$ the 'Khanaqin standoff' highlighted the very real possibility for KRG-GoI violence over the DIBs. ${ }^{(14)}$ The security situation remained fragile and contested for years to come.

The rise of ISIS in 2014 resulted in the complete withdrawal of federal forces from northern Diyala, creating a security vacuum. The void invited both Kurdish forces and the PMF, particularly Badr, to extend their reach across the region through liberation operations. In the three years that followed, each side used forms of patronage to win over supporters. While Khanaqin centre was never taken by ISIS and came under nearly uncontested Kurdish control, a deal between the PUK and Badr stipulated that Kurdish forces were to be granted control over the town of Jalawla while Badr would have jurisdiction over nearby Sadiyah. Badr's foothold into Khanaqin would only increase from the takeover of Sadiyah in 2015.

\section{Khanaqin}

With the independence referendum and the assertion of GoI control in October 2017, the Peshmerga were forced out of Khanaqin. The victorious PMF were compelled to tread carefully in their move to assert control, however. Badr and AAH planned to come into Khanaqin alongside the Iraqi Army - branding themselves as a unified PMF. ${ }^{(15)}$ These attempt was challenged locally with huge anti-PMF rallies. ${ }^{(16)}$ The Diyala chief of police at the time, a Badr affiliate himself, claims he had to personally exhort Badr and AAH military commanders against entering the city. $\mathrm{He}$ performatively stood in front of the photo of Jalal Talabani and saluted it before the protestors, declaring that Badr and AAH troops would never be allowed into the city. In this way, he partially aligning himself with the moral populism of Kurdish nationalism. ${ }^{17}$ In general, Badr-backed federal functionaries have adopted a public

\footnotetext{
${ }^{(13)}$ Gareth Stansfield and Liam Anderson, 'Kurds in Iraq: the struggle between Baghdad and Erbil', Middle East Policy, March 2009; 16(1):134-45

${ }^{(14)}$ Quil Lawrence, 'A Precarious Peace in Northern Iraq', Middle East Report, 2009.

(15) Interview with Head of Asayib Ahl al-Haq's (AAH) coordination office in Jalowla, October 2018.

(16) Rudaw, 'One killed, three wounded in protest in Khanaqin', Rudaw.net, October 19, 2017. Available at: http://www.rudaw.net/english/kurdistan/191020177

${ }^{(17)}$ Interview with Chief of Police, Khanaqin, September 2018.
} 
rhetoric of rebuffing the Badr and AAH military wings, accordingly succeeding in operating with a veneer of legitimacy among the Kurdish population. However, these functionaries are generally perceived to be beholden to the broader Badr-controlled political apparatus, ${ }^{(18)}$ which is rooted in the office of the Governor in Baquba.

Badr and AAH troops have taken up posts outside the city as a compromise position and limited their official presence in the district centre to their political offices. Their presence however remains significant and highly securitised. The PMF occupy a prominently situated building opposite the mayor's office atop a hill, with staff and security forces housed within the headquarters mostly Badr members. AAH maintains its headquarters along the southern fringe of the cit, having posted a large picture of their controversial leader Qays Khazali on the main road to be seen by anyone entering or leaving the city from the south. ${ }^{(19)}$ Security in the city centre is officially shared but is actually dominated by the federal authorities under heavy Badr influence. Kurdish intelligence and security forces (Asayish) are permitted to stand at checkpoints alongside Iraqi police, though they have been stripped of the authority to make arrests. The arrangement, which Badr and the PUK struck under Iranian mediation, aimed to appease the large pro-KRG Kurdish population of Khanaqin. Badr commanders noted that they had local Kurds on payroll within the city that could be mobilised within minutes in the event of a security emergency. ${ }^{(20)}$ The PMF have support at all levels of government, including the Badr-backed Governor of Diyala, who praises the 'strong relations and coordination between the province's security forces and the PMF'. (21)

Administratively, Badr-backed federal authorities did not force out all the existing Kurdish, predominately PUK, administration. They permitted the copresence of KRG and GoI administrations for the provision of public services. However, the centre of political control has shifted towards the federal ministries, the governorate capital of Baquba and the Badr-backed provincial administration. The

\footnotetext{
${ }^{(18)}$ Interviews with Kurdish and Sunni Arab community leaders in Khanaqin, August - November 2018.

(19) The US government has debated whether to designate Khazali a terrorist.

${ }^{(20)}$ Interviews with brigadier commanders within Badr in Khanaqin, September - October 2018.

${ }^{(21)}$ Interview with Muthana al-Timimi, Diyala Governor, Member of Badr Organization, Interview in Arabic, Baquba - at the Governor's office. September 2017.
} 
mayor's office and directors now execute their duties with the knowledge that the governorate authorities control the bulk of Khanaqin's salary distributions. The mayor, a PUK affiliate, is mindful of the new realities of the political marketplace and does not want Kurds to be cut out of the government payroll. ${ }^{(22)}$

\section{Sadiyah}

PMF factions controlling Khanaqin District work together but are not united. Both Badr and $\mathrm{AAH}$ have sought to gain the upper hand in the subdistricts surrounding the city centre. It is in Sadiyah that Badr wields the firmest hold over security. Privately, Badr's leadership regards Sadiyah as 'an incubator of terrorism' given that Sunni Arabs make up the majority of the town's population and many allegedly sided with ISIS. ${ }^{(23)}$ Yet in public, Badr has made overtures to the local Sunni community. One Badr commander noted: 'We have tried to forge good local relations and have provided some of the Sunni Arab men with weapons. How do you think Badr got the most votes in Sadiyah during the last [May 2018 parliamentary] elections?'(24) A high-ranking government official from Sadiyah complained that his former bodyguard was granted a 'handsome salary, a piece of land and a house' in exchange for joining Badr ranks as a commander. ${ }^{(25)}$ But the strength of the political marketplace has not been enough to win over everyone. A Sunni Arab IDP from Sadiyah noted:

Security forces that are now in Sadiyah are not from the area. The PMF and the Iraqi Army are mostly from southern Iraq and don't understand the area and its people. I don't go back to Sadiyah because I cannot. My house has been destroyed, and our goods and properties have been looted. ${ }^{(26)}$

Some Sunni Arab leaders have even called for a local Sunni Arab force to secure the area and expel the PMF. ${ }^{(27)}$

\footnotetext{
(22) Interviews with Muhammed Mulla Hassan Mayor of Khanaqin and select PUK officials, September - November 2018.

${ }^{(23)}$ Interview with Badr officials in Diyala, September - October 2018.

${ }^{(24)}$ Interview with Badr commander in Sadiyah, October 2018.

${ }^{(25)}$ Interview with Ahmed Zargushi, Mayor of Sadiyah, October 2018.

(26) Interview with Sunni Arab IDP from Sadiyah in Khanaqin camp, October 2018.

(27) Interview with Abdul Khaliq al-Azawi, former Diyala Governorate Council Member, October
} 


\section{Jalawla}

AAH is dominant in the mixed Kurdish and Sunni Arab town of Jalawla. AAH, a pro-Iran militia accused of committing anti-Sunni atrocities in other parts of Iraq, gained support among local Sunni Arabs by exploiting a key commodity within northern Diyala's political marketplace: the right to return. Between 2016 and 2017, during the period of Kurdish control, the Peshmerga had expelled certain Sunni Arab residents allegedly affiliated with ISIS. Following GoI takeover, the AAH granted many of them return and a salary in exchange for conscription within their ranks. The political marketplace is heavily slanted against Sunni Arabs. Given their political vulnerability, they have little choice but to pledge allegiance to the PMF in exchange for safety, security and financial stability. In Jalawla, the AAH control all major revenue-generating channels and man checkpoints on commercially strategic roads, imposing taxes on vehicles passing through, and earning an estimated daily amount of $\$ 300,000$ in fees, according to a PUK government official. ${ }^{(28)}$

With the rising potential of an ISIS resurgence in northern Diyala, ${ }^{(29)}$ the Asayish have repeatedly exhorted Badr to intervene and stop the AAH's reliance on former ISIS members as recruits, but there is little Badr can do to control its fellow PMF member. Khazali, whose party won 15 seats in the most recent parliamentary election, is now a formidable force both militarily and politically. Given these electoral successes, AAH members in Jalawla and across Khanaqin understand the importance of establishing the party as a quasi-legitimate political entity. The head of the AAH office in Jalawla diplomatically framed the policy of embracing the Sunni Arabs of Jalawla as a matter of cross-sectarian co-existence: 'Our door is open to all sects, ethnicities, groups and tribes, and we have held meetings with different sections of society in Jalawla. We do not want people to feel discriminated against. We want all citizens to sense justice and equality. ${ }^{30)}$

However, the PUK and Sunni Arab leadership of the area rejected this rhetoric

\footnotetext{
2018.

${ }^{(28)}$ Interview with PUK subdistrict council member in Jalowla, October 2018.

(29) Michael Knights and Alex Mello, 'Losing Mosul, regenerating in Diyala: How the Islamic state could exploit Iraq's sectarian tinderbox', CTC Sentinel, October 2016; 25.

${ }^{(30)}$ Interview with Head of Asayib Ahl al-Haq's (AAH) coordination office in Jalowla, October 2018.
} 
and described an overall state of lawlessness. A Sunni Arab politician from Sadiyah noted: 'Chaos reigns in Khanaqin, Jalawla and Sadiyah, where Hashd [PMF] and the Iraqi military rule... People support them out of fear. ${ }^{31}$ Badr leaders were familiar with such accusations and they blamed 'radicals' within the organisation, the AAH and even the Iraqi Army for abuses. ${ }^{32}$ These accusations indicate that the political marketplace is the organising concept in an emerging political rhetoric. Badr seeks to establish itself as the long-term keeper of the peace and order by rhetorically placing itself above the political marketplace. For now, it seems that the local Kurdish and Sunni Arab populace is not convinced.

\subsection{Eastren Salahaddin : Intercommunal Violence and Moral Populism in Tuz}

\section{Khurmatu}

Tuz Khurmatu, a commercial centre and transport hub in the northeast of Salahaddin, has witnessed more violence than any other area of the disputed territories, most recently between the Kurdish and Shi a Turkman communities. Tensions initially arose in the years following the fall of the regime in 2003 due to the political dominance of the Kurds, who took advantage of US backing and occupied the buildings of the former Iraqi regime. They held the office of the mayor and other key positions, and sought to administratively align the city with Kirkuk over and above Tikrit. Ultimately, they filled the political and governmental vacuum in the district, leaving the large Turkman and Arab communities of Tuz Khurmatu mostly powerless. ${ }^{(33)}$

In the ensuing months and years, the Turkman community, who views Tuz as a key Turkman cultural capital and historic population centre, resented the outsized influence of the KRG and the capacity of the Kurdish parties to buy local influence through payroll distributions. ${ }^{(34)}$ When the Turkmen and Arabs began to complain

\footnotetext{
${ }^{(31)}$ Interview with Sunni Arab member of Sa'adiya District Council, October 2018.

${ }^{(32)}$ Interview with PMF Brigade Commander and former Badr Organization member, September 2018.

(33) Interview with Kurdish and Turkmen government and political party officials in TuzKhurmatu, October 2018.

(34) Interview with Kurdish and Turkmen government and political party officials in TuzKhurmatu, October 2018.
} 
about the 'Kurdification' of Tuz Khurmatu in 2004 and 2005, US forces and administrators took limited measures to balance out the local distribution of power. They raided KDP and PUK political headquarters in Tuz, demanding full disarmament, while continuing to provide broader support for the Kurds of Tuz. ${ }^{(35)}$ The Peshmerga formed the core of the local US-backed Iraqi Civil Defense Corps, which eventually became the $16^{\text {th }}$ Brigade of the US-trained Iraqi Army. By 2010, 70 percent of the $16^{\text {th }}$ Brigade remained Kurdish and engaged in regular joint counterterrorism operations with US forces. ${ }^{(36)}$ Turkmen resentment towards the Kurds and the US-Kurdish alliance ultimately coalesced into a violent resistance. Elements within the Sunni Turkmen community joined al-Qaeda alongside Sunni Arabs, and Shi' a Turkmen joined ranks with the Mahdi Army.

Kurdish leaders in Tuz would reject any notion that their political position was arbitrarily favoured by the American invasion. They justified their dominance over post-2003 politics as the natural reversal of Saddam era policies. The reasoned that Saddam separated Tuz from Kirkuk and merged it with Salahaddin in 1976 in order to reduce the Kurdish population of the oil-rich province, and that they were now merely restoring the natural political order. In truth, both the Kurdish and Turkman populations of Tuz could point to historical markers of victimhood. Both were subjected to violence and displacement during Saddam's Anfal campaign. ${ }^{(37)}$

\footnotetext{
(35) Interview with Kurdish former military commanders in Tuz-Khurmatu, November 2018.

(36) Interview with the former commander of the $16^{\text {th }}$ Brigade of the U.S. trained Iraqi Army. November 2018.

${ }^{(37)}$ Interviews with Kurdish and Shi a Shi a Turkman community leaders, residents, and local government, October - November 2018.
} 
Map (3) Iraq's Salahaddin Governorate

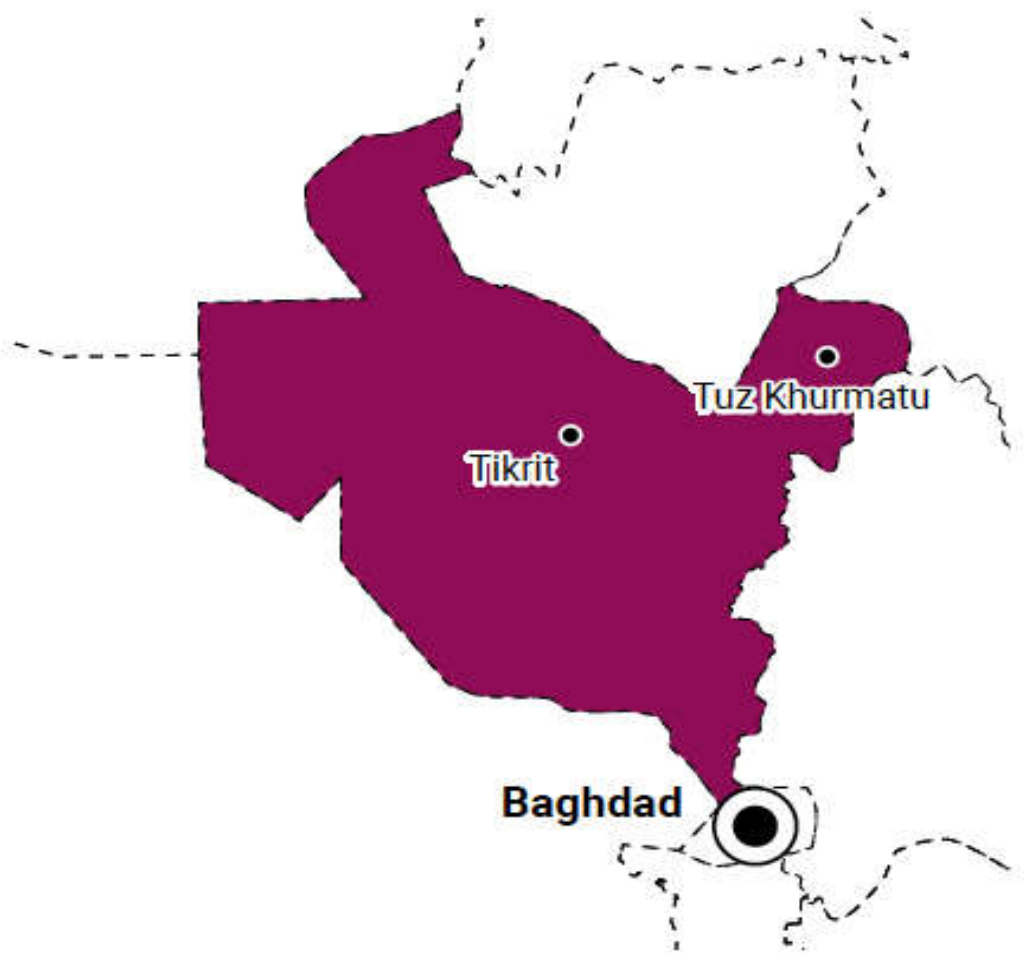

Source: GPPI: https://www.gppi.net/2017/08/16/iraq-after-isil-tuz

As part of the broader sectarian politics of Nouri al-Maliki during the 2010-14 period, which coincided with the 2011 withdrawal of American troops, the Baghdadbased Shi ' a parties directed positions and services to their co-religionists in the Shi 'a Turkman community. The balance of power would gradually start to move in the direction of the Turkmen - specifically the Shi a Turkmen. A new federal security force was established in the district. It comprised almost entirely of Shi ' a Turkmen, a move that the Prime Minister justified as a protective measure due to attacks by radical Sunni Arab elements against them. As both communities increasingly saw the other as encroaching on its hold on power, forms of political speech emerged that 
pitted ethno-nationalist Kurdish and Turkish discourses against one another. What began as a fight over resources and power quickly became infused with violent sectarian rhetoric.

With tensions already running high, the threat of ISIS and the withdrawal of federal forces created a security vacuum in the district. Unlike Khanaqin, where a relatively homogenous Kurdish populace resisted the military influence of Badr, in Tuz Khurmatu, Badr and the PMF would find local support in the Shi' a Turkman community. After a brief period of complete Peshmerga control 2014, an Iranbrokered deal allowed Badr to assert control over certain areas of Tuz district, particularly those with large Shi a Turkman populations such as Amirli. Throughout 2015 and 2016, political and military control of Tuz splintered off into arenas of influence for the Peshmerga, Badr and other PMF factions. Shi ' a Turkmen joined the ranks of the PMF flowing into the district from the southern provinces. The securitisation of the city engendered intense periods of violence.

On two separate occasions, in November 2015 and April 2016, street clashes erupted between the Shi a Turkman and the Kurdish sides, ${ }^{(38)}$ with both the Peshmerga and the PMF bringing extra forces into the city. During the second round of clashes, a group of Shi a Turkmen with PMF insignia and Iraqi flags on their chests, and a flag bearing an 'Oh Hussein' inscription hanging on a wall behind them, proclaimed the following: 'We Shi' as stood firm in the face of ISIS, but you Kurds ran away from ISIS...We will bombard and hit you with the rockets of the Islamic resistance [...] we will turn the soil and ground into a mass graveyard for the Kurds and for the sons of Barzani. ${ }^{(39)}$ Meanwhile, the speeches of major Kurdish political figures provoked the Turkmen as stooges of Turkey and stoked Kurdish nationalism among the local population. Moral populism was toxic during these

\footnotetext{
(38) 'Deaths during battles in Tuz-Khurmatu and Al-Abadi intervenes', Al Jazeera, 24 April 2016 [In Arabic]. Available at: http://www.aljazeera.net/news\%2Farabic\%2F2016\%2F4\%2F24\%2F-قتلى-6عارك طوزخورماتو-والعبادي-يتدخل

(39) Youtube Video, 'The Message of Mujahideen of Tuz Khurmatu to the heroes of the PMF', published on May 4, 2016, available at:

https://www.youtube.com/watch?v=Wz74HtaIdfg\&feature=share\&fbclid=IwAR3I_iRG2cDk_V18py 3aoEzHgYzDTwqU7GEO1NtH-SBZ4PPRsoncmghNyWw
} 
episodes of violence.

The clashes resulted in the injury and death of more than 20 fighters in total from both sides. During these episodes of violence in Tuz Khurmatu, schools were closed and people stayed home for weeks out of fear of becoming targets of snipers. Several meetings failed to put an end to the tensions. Kurdish political figures contacted the leaders of the Shi' a parties in the south and urged them not to back members of Tuz's Shi 'a Turkman community. In these overtures, Kurds accused the Turkish intelligence services of using the Shi a Turkmen to challenge the KRG's

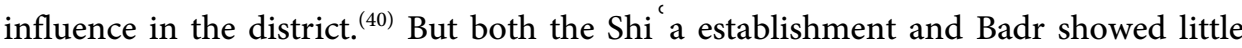
sign of accepting this line of argument. It is likely that growing intra-Shi a rivalries between AAH and Badr, which grew particularly intense in the areas of Tuz liberated from ISIS, ${ }^{(41)}$ scuttled the possibility for a unified deal with the Kurds. When Peshmerga leaders demanded the PMF to leave the central district, Hadi al-Ameri personally intervened to reject the idea. In a press conference, he asserted that 'we in the PMF are no strangers to the area and we will remain'. ${ }^{(42)}$ This claim about the indigeneity of the PMF signalled to the local Shi' a Turkman community that they were the means through which the PMF would continue to claim legitimacy.

This inter-communal strife culminated with the September 2017 Kurdish independence referendum. Following the advance of federal forces and PMF and the retreat of the Peshmerga in October, 50,000 Kurds fled the city for fear of violent reprisals. Shi a Turkmen and elements within Badr and the AAH burned down houses of Kurdish officials, Peshmerga members and Kurdish residents. ${ }^{(43)}$ Badr

\footnotetext{
${ }^{(40)}$ Interviews with Kurdish politicians and Peshmerga leaders in Tuz Khurmatu, November 2018.

(41) Christine van den Toorn, 'High Noon in Iraq's Wild West', Foreign Policy, 22 February 2016. Available at: https://foreignpolicy.com/2016/02/22/high-noon-in-iraqs-wild-west/

(42) 'Tuz-Khurmatu: meeting between Peshmerga and the Shi 'a PMUs ends with no results', Al Jazeera, 27 April 2016. Available at:

https://www.youtube.com/watch?v=JLDsuONfrZs\&feature=share\&fbclid=IwAR1ciU_SuKiyUNEaB D8xBE54d4Qw-Kl1CsLRAT0bLu_ZBbtpEcqV_psC6Zg

${ }^{(43)}$ Interview with Kurdish officials and residents of Tuz Khurmatu, November 2018. See also 'Iraq: Fresh evidence that tens of thousands forced to flee Tuz Khurmatu amid indiscriminate attacks, lootings and arson', Amnesty International. October 2017.
} 
officials blamed these incidents on radical elements within their own ranks. ${ }^{(44)}$

Three weeks later, the GoI intervened to broker a deal for the return of the Kurds to the city. With the backing of the Prime Minister's office, GoI officials met with Kurdish and Turkman community leaders in Tuz and convinced them to allow a neutral government force, the Rapid Response Forces (RFF), to protect the peace and facilitate return. The arrival of the force in January 2018 led to a thaw in the violence and the return of many Kurds. ${ }^{(45)}$ However, the return of Kurdish families has not resulted in a restoration of their former political power. While Badr and AAH do not have military bases inside the central district, they maintain several strategically-located bases a few kilometres outside the city centre: Brigade 52 of the PMF, mostly Badr forces, are stationed at nearby Sadiq Airfield, used by US forces as their Tuz headquarters until 2011; ${ }^{(46)}$ Badr convoys move through the city at will; the PMF has established total control over the city administration, controlling all the major posts; and Badr-backed elements have replaced Kurdish governmental functionaries with Shi a Turkmen.

As Badr has assumed effective control over Tuz, its leadership now faces a vexing conundrum: they enjoy local influence because of the Shi' a Turkman community, but the radicalism of this community's moral populism, which has also gained momentum among the secular Iraqi Turkman Front Party, renders governance of a diverse city exceedingly complex. ${ }^{(47)}$

With both the Shi a Turkmen and their secular counterparts emboldened, Hadi al-Ameri has taken the tack of empowering Badr-backed technocrats as official administrators in order to keep the peace with the Kurds while simultaneously appeasing radical Turkmen with the lion's share of actual power. An Arab district

\footnotetext{
${ }^{(44)}$ Interviews with Badr commanders and Badr affiliates, August - November 2018.

${ }^{(45)}$ Interview with Ayub Dawdi (Kurd), Deputy Mayor of Tuz-Khurmatu and Head of Department for Displaced Persons, September 2018.

${ }^{(46)}$ Interview with government and various political party officials in Tuz-Khurmatu. December 2018.

(47) Youtube video, 'A Turkmen MP threatens the Kurds and characterizes them as terrorists', April 11, 2018. Available at:

https://www.youtube.com/watch?v=u0JxIhDJfYo\&feature=share\&fbclid=IwAR33Od1eXF6fYd5uF2M9k9VKIAclY5Ht0SXTL2o7CW0eFhMkv-6Ae81JwU
} 
council member in Tuz claimed: 'The mayor is absolutely powerless. He has been surrounded by advisers appointed by Shi ' a militia parties in his office. ${ }^{(48)}$ The mayor openly admitted that influential figures within Badr and AAH regularly imposed their agendas on him. He has even received a letter signed by Ameri himself ordering him to comply with any and all orders from a certain Shi 'a Turkman Badr leader. The mayor characterised the Badr representative as his main rival in the district even though again the mayor is himself aligned with Badr. ${ }^{(49)}$

While the mayor and other elements within the Badr-backed federal administration are concerned about the extreme anti-Kurdish moral populism and violence of the Shi a Turkman militias, the realities of the political marketplace force these administrators into a weak position. The mayor clarified: 'The [Badr] leadership listens to those who provide them with cash, which I do not have. Armed groups make money and are therefore favoured by the leadership.' Both AAH and Badr are active participants in a political marketplace fuelled through a war economy. According to a high-ranking Shi a Turkman official in Tuz, AAH's 'economic committee' has been using employees within various service offices to collect taxes from all types of businesses including shops, private clinics, restaurants and block factories. ${ }^{(50)}$ In addition to cash collected at checkpoints along strategic commercial roads, ${ }^{51}$ this money is in turn used to purchase the influence that the mayor himself lacks. ${ }^{(52)}$

The periods of intercommunal violence are still fresh on the residents' minds. Darbaz Mohammed, former Minister of Migration who helped broker the deal facilitating the entrance of the RRF into the city, cautioned against any hint of optimism:

Tuz Khurmatu is like a time bomb that could explode at any minute. For Tuz to return to communal war, it only requires murdering a young Shi a Turkman, which

\footnotetext{
${ }^{(48)}$ Interview with Sunni Arab District Council Member in Tuz Khurmatu, November 2018.

${ }^{(49)}$ Interview with Hassan Zain Abdeen, Mayor of Tuz Khurmatu, November 2018.

${ }^{(50)}$ Interview with a high-ranking Shi ' a Turkman government official in Tuz, November 2018.

(51) Mark DeWeaver, 'Decentralized Rent Seeking in Iraq's Post-ISIS Economy: A Warning from the Concrete Block Industry', Institute of Regional and International Studies. August 2017.

${ }^{(52)}$ Interview with a high-ranking administrative official in Tuz, November 2018.
} 
would definitely ignite a civil war in the town. There are armed groups ready to take advantage of any development...'(53)

Unfortunately, in the summer of 2018 the GoI was forced to withdraw parts of the RRF and redeploy them to Basra, where popular protests threatened the province's stability. It replaced the departed RRF with regular Iraqi Army units, which a Kurdish administrative official from Tuz claimed were mostly Shi a Arabs sympathetic to the Shi a Turkmen. ${ }^{(54)}$ Meanwhile, moral populism remains toxic on both sides, although the Kurds are forced to limit public expression of their views. One Kurdish community leader privately noted during a November 2018 interview: 'Once the balance of power has shifted and we are in control again, the Kurds and the Sunni Arabs will kill every Shi ' a Turkman in the city. We will never forget what they did to us.' ${ }^{\text {(55) }}$

\section{Conclusions}

Despite the severity of these expressions of ethno-sectarian differences, the one sentiment that united all constituents within northern Diyala and Tuz Khurmatu was a complete dissatisfaction with public services. In the past, such expressions of discontent were quickly diffused through a two-way blame game with the GoI pinning administrative failures on the KRG and vice versa. However, following the events of October 2017, the GoI lacks excuses as the KRG and Kurdish parties no longer hold any plausible responsibility over the DIBs. Members of local government from all ethnicities claimed that neither Baquba (the capital of Diyala) nor Tikrit (the capital of Saladin) sent any funds for public works and services. They added that provincial governments still operated under the old thinking that Khanaqin and Tuz were peripheral second class cities outside their immediate realm of concern and influence.

Accordingly, public authority ${ }^{(56)}$ at the administrative level is fractured to the

\footnotetext{
(53) Interview with Darbaz Mohammed, Former Minister of Migration and Displacement, November 2018

${ }^{(54)}$ Interview with a Kurdish administrative official in Tuz, November 2018.

${ }^{(55)}$ Interview with a Kurdish community leader in Tuz Khurmatu, November 2018.

(56) Toby Dodge et al., 'Iraq Synthesis Paper: Understanding the Drivers of Conflict in Iraq', LSE
} 
point of disintegration. Badr, AAH and other PMF factions hold power over security but lack the funds, expertise and bureaucratic coherence to effectively administer services and engage in reconstruction. This is an area where the new ministries forming in Baghdad can immediately gain leverage in the disputed territories. While the security sector will likely remain in the hands of the PMF in the near future, the international community must work with the GoI to empower district and subdistrict level governments and grant them the funds and expertise to administer services. Even if these local governments are under Badr influence, as the above cases suggest, Badr is not a coherent monolithic entity. Strengthening moderate federal administrators by providing them with reconstruction funds and service capacity could increase the material and symbolic presence of the GoI.

Failure to support local government with adequate capacity and funds will only lead to increased concentration of the means of revenue generation in the hands of armed groups, effectively entrenching a political marketplace fuelled by a war economy. Smuggling and illegal taxation through checkpoints flourish across the DIBs. These illegal activities have been carried out by armed actors with links to influential political parties in Baghdad, who have sought to increase patronage networks and the position of allies. ${ }^{(57)}$ Any plan to strengthen the capacity of local government must ensure that state funds are monitored and only maintained on the condition of equitable service delivery and employment across the various local political and ethno-sectarian constituents. A strengthened public sector and local government will only gain legitimacy if it counters the current prevailing system of patronage.

Specific community grievances must also be addressed. Just as the GoI was successful in facilitating the return of internally displaced persons (IDPs) to Tuz by sending the RRF, it can gain further local legitimacy by facilitating the return and compensation of IDPs across the DIBs. In Khanaqin, for instance, the presence of

Middle East Centre-Conflict $\quad$ Research $\quad$ Programme, 2018. Available at:
http://www.lse.ac.uk/international-development/Assets/Documents/ccs-research-unit/Conflict-
Research-Programme/crp-synthesis-paper/Iraq-synthesis-paper-understanding-the-drivers-
2018.pdf
(57) Interviews with local politicians, admisntarive officials, and citizens in Diyala and Tuz-
Khurmatu, September - November 2018.


Sunni Arab IDPs in the district centre stokes Kurdish fears of 'a new method of Arabisation by the Baghdad government', giving Kurdish ethno-nationalist parties rhetorical ammunition to generate anti-Arab and anti-Baghdad feelings. Finding a solution for the IDPs in Khanaqin would lessen the potency of this rhetoric. Simultaneously, the GoI must help in fulfilling justice for civilians from all sides whose properties have been damaged and looted and whose family members have been killed. The remnants of destroyed and burned buildings indicate past episodes of violence and must be remedied if stability and intercommunal trust is to be restored.

The window for a grand Erbil-Baghdad deal is quickly closing, or may already be closed. In addition to the fragmentation of the PMF and the Shi a political bloc, there are major tensions and divisions within the KRG. During the October 2017 Kurdish withdrawal from the DIBs, the KDP accused the PUK of treason and siding with the GoI. It is highly unlikely that the PUK and KDP, and much less the various constituents within the GoI and PMF umbrella, will come to a holistic agreement at any point in the foreseeable future. But this should not compel the GoI and KRG, in addition to regional and international partners, to adopt a position of disengagement. A continuation of the status quo, in which the DIBs become an increasingly hostile point of competition among armed actors, will only benefit ethno-nationalists among the Kurds, Sunni and Shi ' a Arabs and Shi a Turkmen, allowing them to tap into moral populism to mobilise political support. This would eventually lead to a sidelining of more moderate and pro-reformist movements, civil society organisations and parties within the KRI and the rest of Iraq, and invite the outsized influence of regional actors.

While it is theoretically possible that Baghdad will find a pathway to provide services and security in the DIBs and consolidate the various factions behind the central government, it is more likely that the political field will continue to fragment and benefit quasi-governmental groups such as the PMF, specifically the radical factions of Badr and the AAH. If this were to transpire, the short and long-term implications would be severe: Ethno-nationalists among the Kurds, Sunni and Shi 'a Arabs, and Shi ' a Turkmen would be able to capitalise on the tensions in the disputed territories to increase social capital within core Kurdish and Arab areas. This would 
eventually sideline more moderate and pro-reformist movements, and the more compromising administrators and functionaries within Badr. Such a development would only exacerbate the militarisation and securitisation of politics in the KRG and the rest of Iraq, inviting deeper influence from Iran, Turkey and other regional actors.

Any framework for resolving the broader conflict between Baghdad and Erbil must first prioritise curbing the continued fragmentation of administrative and security structures at the local level.

Government of Iraq (GoI): The main priority of the GoI should be to reestablish capacity and professionalism among security forces and administrators. This would include training and expanding federal and local police in addition to respected Army units such as the Rapid Response Force (RRF). Kurds and Sunni Arabs must be encouraged to join the Iraqi Security Forces (ISF), and the usage of sectarian markers of affiliation should be entirely banned. Given the preponderance of criminal groups and illegal rent-seeking on roadways, all checkpoints should be manned by professional federal forces. Government jobs and resources for public projects such as electricity, water and municipal buildings must be restored and distributed equitably and without favouritism to ethno-sectarian affiliation.

Kurdish Regional Government (KRG): While the security presence of the KRG will likely remain diminished in the short-term, Kurdish leaders should cooperate wherever possible with the ISF in order to ensure continued protections for Kurds residing across the disputed territories. Administratively, the KRG must move quickly to develop a reasonable employment status for the thousands of employees on KRG payroll who no longer hold positions following the GOI reassertion. Finally, KDP and PUK leaders should avoid inflammatory ethno-nationalist rhetoric at all costs. Ultra-nationalist language is a politically expedient driver of support within the areas under KRG control; however, the same rhetoric often exposes Kurds to violence in the disputed territories due to heightened tensions between groups.

United Nations Assistance Mission for Iraq (UNAMI): While commencing talks over a final deal may not be possible under the current political environment, it 
is entirely possible and necessary for local-level mediations on more limited issues (e.g. property claims, equitable government employment and integrated security arrangements) to proceed with the end of reducing simmering tensions between the federal and Kurdish sides. In determining priority areas for intervention, UNAMI mediation teams should avoid excessive emphasis on Kirkuk at the expense of often neglected but strategically crucial, areas such as northern Diyala and Tuz Khurmatu.

International Community: Donor-funded NGO projects which build infrastructure, train administrators, and strengthen civil society should be encouraged as they will complement the GoI's efforts to restore legitimate forms of public authority. In general, the international community must widen engagement with the disputed territories beyond narrowly-defined energy interests and efforts to fight terrorism.

The GoI must prioritise and move quickly. If the current disintegration of public authority were to continue unabated, the short and long-term implications would be severe: Ethno-nationalists among the Kurds, Sunni and Shi ' a Arabs and Shi a Turkmen would be able to capitalise on the tensions in the disputed territories to increase social capital. Such a development would only exacerbate the militarisation and securitisation of politics in the Kurdistan Region of Iraq (KRI) and the rest of the country. 


\section{List of interviews:}

Abdul-Hussein Abbas (Known as Hakm Shaho), the ousted mayor of Mandali, Interview in Arabic, Khanaqin (26/06/2018).

Abdullah al-Jaburi: a Sunni Arab former MP from Diyala. Interviewed October 17, 2017.

Abu Kazim, Head of Assayb Ahl al-Haq's (AAH) coordination office in Jalaula, a Shia

Arab from al-Muqtadia, interviewed at AAH's office in Jalaula on October 13, 2018.

Abu Ziyad al-Qeisy : a Sunni Arab member of AAH in Jalaula, from Jalaula, Interviewed on October 13, at AHH's office, Jalaula.

Adnan Ismael Khalil, Sa'adiya District Council Member, Sunni Arab, from Sa'adiya. Interviewed on October 13,2018 ,

Adnan Mansoor, Head of Khanaqin's directorate of article 140 . Interviewed On September 02, 2018.

Ahmed Zargushi, The Mayor of Sadiya district, and the acting Mayor of Jalaula, from Sadiya. Interviewed on Octber 17, 2017.

Ala'a Ibrahim, social activist and works as a Nurse at Jalaula's main Hospital, from

Jalaula, Sunni Arab, Interviewed on October 13, 2018.

Ali Ghazi, Head of Iraq's Displacement and Migration Office in Khanaqin. Interviewed on October 16, 2018.

Ali Hassan Rashid, Tuz's Police Chief, Shia Turkmen, interviewed on November 21, 2018

Arif Adil, director of Jabarah Sub-district. He was interviewed in his office in the town of Jabarah on September 27,2018.

Ayub Dawdi (Kurd), deputy mayor of Tuz-Khurmatu and head of IDPs department in Tuz-Mayor, in his office on September 19, 2018.

Badr leader (Abu Muntazar) - Khanaqin(09.06.2018). 
Diyari Shawkat, Khanaqin's police chief - the police force controlled by the Diyala governorate (23.08.2018).

Dr. Derbaz Muhammed, Iraq's Minister of Migration and Displaced Peoples, Interview in Arabic, Suleimaniya [Regarding his role in the Tuz agreement] .

Dr. Hassan Zain Abdeen, newly appointed mayor of Tuz-Khurmatu. He is Turkman and member of Badr Organization.

Hassan Najm Abdulla (known as Mamosta Hassan), the head of the KRG's education sector in Khanaqin. (28.09.2018).

Hussein Karawi, leader of head of Asayb Al-Ahl Haq in Qara Tapah and Jalawla.He was interviewed in his home in Qara Tapah on September 27,2018.

Ibrahim Abood Najim, an Arab member of Jalawla's City Council, Interview in Arabic, Khanaqin, $(26,09,2018)$.

Jalawla's mayor Shex Yaqub, Interview in Arabic, Suleimaniya (25/06/2018).

Khalil Sayyid Agha Baba, member of Khanaqin City Council, interview in Arabic, Khanaqin, (26.09.2018).

Luqman Daudi, organizer of families who transferred their food-portion form to TuzKhurmatu and Tawuq: He was interviewed in his home in Tauwq on September 18, 2018.

Masud Dara-Khana, member of the PUK organizational branch in Khanaqin ( head of election chamber), member of the Supervisory Body of the September 25, 2017 referendum for independence in Khanaqin. Interviewed on October 17, 2018.

Muhammed Mulla Hassan, the mayor of Khanaqin(25.08.2018).

Mulla Hassan, Salahuddin District Council Member from Tuz, Kurdish, interviewed on November 16, 2018.

Mustafa Kamal Adham, a Turkmen member of Khanaqin's City Council, Interview in Arabic, Khanaqin (26.09.2018). 
Muthana al-Timimi, Diyala Governor, Member of Badr Organization, Interviewed on September 17, 2018.

Raeed Khalid Mandalawi, a member of Mandali's town Council - now acting head of the Council, interviewed on September 06, 2018.

Rahim Aziz, head of Qara Tapah town council. Interview October 2, 2018 in the office of Kifri Mayor.

Sa'ad al-Tamimi, Hashd Brigade Commander/ former Badr Organization member, Shia Arab. Interviewed On September 18, 2018.

Said Ismail, organizer of families who transferred their food portion for disputed areas in Kifri: He was interviewed in Zinana on October 2, 2018.

Salah Ahmed Muhammed, a member of Jalawla's Town Council, Interview in Arabic, Khanaqin (26.09.2018).

Salih Mahdi, Tuz district council member, Sunni Arab, interviewed on November 22, 2018.

Sardar Ahmed, Tuz district council member, Kurdish, interviewed on November 22, 2018.

Sayid Ali, Badr member, spokesperson for the PMUs in Tuz and the deputy head of Tuz's district council - Shia Turkmen, interviewed on November 21, 2018.

Shalal Abdul, former mayor of Tuz. Interviewed on October 02, 2018.

Shekh Thair Albayati, Secretary of Arab Tribal Council in Tuz-Khurmatu; intervewed on October 2, 2018.

Tahir Ahmed (Mamosta Tahir), member of the PUK organizational branch - Tuz. Member of the Supervisory Body for the Kurdish referendum of independence of September 25, 2017 in Tuz. interviewed on November 18, 2018-12-16.

Zaid Abdullah , police officer, Khanaqin Police headquarter, Sunni Arab -,Interviewed October 16, 2018. 
Zyiad Ezat, a Sunni Arab IDP who lives in Khanaqin camp, from Sadiya and used to be a farmer there. Interviewed on October 16, 2018.

\section{References}

Al Jazeera, 'Tuz-Khurmatu: meeting between Peshmerga and the Shi' a PMUs ends with no results', , 27 April 2016. Available at: https://www.youtube.com/watch?v=JLDsuONfrZs\&feature=share\&fbclid=IwAR1ciU_SuKiy UNEaBD8xBE54d4Qw-Kl1CsLRAT0bLu_ZBbtpEcqV_psC6Zg

Al Jazeera, 'Deaths during battles in Tuz-Khurmatu and Al-Abadi intervenes', , 24 April 2016 [In Arabic]. Available at:

http://www.aljazeera.net/news\%2Farabic\%2F2016\%2F4\%2F24\%2F- قتلى-بعارك-طوزخورماتو والعبادي-يتدخل

Bartu ,Peter, 'Wrestling with the integrity of a nation: the disputed internal boundaries in Iraq', International Affairs. 1 Nov 2010; 86(6):1329-43.

BBC News, 'Iraq takes disputed areas as Kurds 'withdraw to 2014 lines', BBC online, 2017. Available at https://www.bbc.com/news/world-middle-east-41663350;

De Waal , Alex, 'Introduction to the Political Marketplace for Policymakers', JSRP Policy Brief, March 2016.

Dodge ,Toby et al., 'Iraq Synthesis Paper: Understanding the Drivers of Conflict in Iraq', LSE Middle East Centre-Conflict Research Programme, 2018. Available at: http://www.lse.ac.uk/international-development/Assets/Documents/ccs-researchunit/Conflict-Research-Programme/crp-synthesis-paper/Iraq-synthesis-paperunderstanding-the-drivers-2018.pdf

Gaston, Erica and Derzsi-Horváth , András, 'Iraq after ISIS: An Analysis of Local, Hybrid, and Sub-State Security Forces', GPPi, 27 December 2017. Available at: https://www.gppi.net/2017/12/27/iraq-after-ISIS-an-analysis-of-local-hybrid-and-sub-statesecurity-forces

Knights ,Michael and Mello, Alex, 'Losing Mosul, regenerating in Diyala: How the Islamic state could exploit Iraq's sectarian tinderbox', CTC Sentinel, October 2016; 25.

Lawrence, Quil, 'A Precarious Peace in Northern Iraq', Middle East Report, 2009. 
Mansour, Renad and Abd al-Jabbār , Fāliḥ, 'The Popular Mobilization Forces and Iraq's Future', Carnegie Endowment for International Peace, 2017. Available at: https://carnegie-mec.org/2017/04/28/popular-mobilization-forces-and-iraq-s-future-pub68810

Morris , Loveday, 'How the Kurdish independence referendum backfired spectacularly', The Washington Post, 20 October 2017. Available at:

https://www.washingtonpost.com/world/how-the-kurdish-independence-referendum-

backfired-/2017/10/20/3010c820-b371-11e7-9b93-

b97043e57a22_story.html?utm_term $=.728 \mathrm{~b} 97 \mathrm{fb} 523 \mathrm{~b}$

Rudaw, 'One killed, three wounded in protest in Khanaqin', Rudaw.net, October 19, 2017. Available at: http://www.rudaw.net/english/kurdistan/191020177

Stansfield , Gareth and Liam Anderson, 'Kurds in Iraq: the struggle between Baghdad and Erbil', Middle East Policy, March 2009; 16(1):134-45

Steinberg, Guido, 'The Badr Organization: Iran's Most Important Instrument in Iraq', German Institute for International and Security Affairs, 2017. Available at: https://www.swp berlin.org/fileadmin/contents/products/comments/2017C26_sbg.pdf

Van den Toorn, Christine, 'High Noon in Iraq's Wild West', Foreign Policy, 22 February 2016. Available at: https://foreignpolicy.com/2016/02/22/high-noon-in-iraqs-wildwest/

Wolff, Stefan, 'Governing (in) Kirkuk: resolving the status of a disputed territory in post-American Iraq’, International Affairs, 86.6 (2010): 1361-1379.

Youtube video, 'A Turkmen MP threatens the Kurds and characterizes them as terrorists', April 11, 2018. Available at:

https://www.youtube.com/watch?v=u0JxIhDJfYo\&feature=share\&fbclid=IwAR33Od1eXF6f Yd5uF2M9k9VKIA-clY5Ht0SXTL2o7CW0eFhMkv-6Ae81JwU

Youtube Video, 'The Message of Mujahideen of Tuz Khurmatu to the heroes of the PMF', published on May 4, 2016, available at:

https://www.youtube.com/watch?v=Wz74HtaIdfg\&feature=share\&fbclid=IwAR3I_iRG2cDk _V18py3aoEzHgYzDTwqU7GEO1NtH-SBZ4PPRsoncmghNyWw 